DOI: $10.15193 /$ zntj/2017/113/208

\author{
PAWEŁ SATORA, DAGMARA CELEJ, MAGDALENA SKOTNICZNY, \\ NINA TROJAN
}

\title{
IDENTYFIKACJA DROŻDŻY OBECNYCH W KISZONEJ KAPUŚCIE KOMERCYJNEJ I OTRZYMYWANEJ W GOSPODARSTWACH ROLNYCH
}

\author{
Streszczenie
}

Kiszona kapusta jest produktem powszechnie spożywanym w Polsce. Otrzymywana jest nadal w sposób tradycyjny w wyniku fermentacji spontanicznej przez rodzime mikroorganizmy zasiedlające liście kapusty, którymi są głównie bakterie kwasu mlekowego. W trakcie fermentacji uaktywniają się także drożdże, których negatywna działalność może prowadzić do podwyższenia pH i rozwoju bakterii gnilnych.

Celem pracy było określenie mikroflory drożdżowej występującej w kapuście kiszonej produkowanej przemysłowo oraz otrzymywanej w wyniku spontanicznej fermentacji w gospodarstwach rolnych w okolicach Muszyny. Mikroorganizmy izolowano przy użyciu agaru WL z dodatkiem chloramfenikolu w ilości $0,1 \mathrm{~g} / 1$, a izolaty różnicowano metodą RAPD-PCR z wykorzystaniem markera M13 i identyfikowano poprzez sekwencjonowanie regionu ITS. Najwięcej drożdży stwierdzono w próbkach kapusty otrzymanych metodami tradycyjnymi w gospodarstwach w gminie Muszyna $\left(2,3 \div 15,9 \cdot 10^{3} \mathrm{jtk} / \mathrm{g}\right)$ oraz w jednym produkcie komercyjnym $\left(2,8 \cdot 10^{3} \mathrm{jtk} / \mathrm{g}\right)$. W pozostałych analizowanych kiszonych kapustach nie stwierdzono ich obecności. Wśród izolatów wykryto przedstawicieli dwóch gatunków drożdży Cryptococcus macerans oraz Debaryomyces hansenii, przy czym drugi z nich został zróżnicowany metodą RAPD-PCR na 3 różne profile elektroforetyczne. Obecność zidentyfikowanych mikroorganizmów była ściśle uzależniona od analizowanej próbki, co mogło być związane z technologią produkcji kiszonej kapusty, a także z odmianą użytego surowca. Występowanie oznaczonych gatunków drożdży w gotowym produkcie może przyczyniać się do skrócenia czasu jego przydatności do spożycia i pojawienia się objawów zepsucia.

Słowa kluczowe: kiszona kapusta, drożdże, PCR-RAPD, sekwencjonowanie, Debaryomyces hansenii

Dr hab. inż. P. Satora, prof. nadzw., mgr inż. D. Celej, mgr inż. M. Skotniczny, mgr N. Trojan, Katedra Technologii Fermentacji i Mikrobiologii Technicznej, Wydz. Technologii Żywności, Uniwersytet Rolniczyw Krakowie, ul. Balicka 122, 30-149 Kraków. Kontakt: psatora@ar.krakow.pl 


\section{Wprowadzenie}

Polska jest czwartym co do wielkości producentem kiszonej kapusty w Europie, a jej roczne spożycie w naszym kraju wynosi ok. $3 \mathrm{~kg}$ na mieszkańca [4]. Produkt ten otrzymywany jest w sposób tradycyjny w wyniku spontanicznej fermentacji przez rodzime mikroorganizmy zasiedlające liście kapusty, którymi są głównie bakterie kwasu mlekowego [1]. W wyniku procesu fermentacji cukry fermentujące, takie jak sacharoza, fruktoza, glukoza i inne, są przekształcane do kwasów organicznych, etanolu, dwutlenku węgla oraz mannitolu. Kiszona kapusta stanowi bardzo ważny produkt żywieniowy ze względu na walory odżywcze. Jest bogata w mające pozytywny wpływ na zdrowie składniki mineralne, witaminę C, antyoksydanty oraz błonnik [8]. Cechuje się również wysokim poziomem glukozynolanów, które wykazują dużą aktywność przeciwnowotworową. Jakość produktu zależy głównie od mikroflory znajdującej się na surowym warzywie [14]. Rozwój mikroorganizmów następujący w odpowiedniej sekwencji jest niezbędny do uzyskania smaku i aromatu charakterystycznego dla kiszonej kapusty [16].

Sposób, w jaki obecnie produkuje się kiszoną kapustę, jest znany od wieków, a jego podstawowe etapy nie uległy zmianom. Polega on na rozdrobnieniu surowca, a następnie wzbudzeniu procesu spontanicznej fermentacji poprzez zapewnienie odpowiednich warunków, takich jak zasolenie oraz ograniczenie dostępu tlenu dzięki upakowaniu i ugnieceniu surowca w pojemnikach.

W pierwszym etapie oczyszczona i pokrojona kapusta jest upakowywana w wannach lub tankach, gdzie dodawana jest do niej sól w ilości $2,25 \div 2,5 \%$. Proces fermentacji rozpoczyna się już w ciągu kilku godzin od zasolenia. Pierwszą fazą jest burzliwa fermentacja, za którą odpowiadają głównie bakterie z grupy coli oraz heterofermentatywne bakterie mlekowe Leuconostoc mesenteroides. Czas jej trwania to ok. 2 - 3 dni, w trakcie których ma miejsce szybkie obniżenie pH połączone ze wzmożoną produkcją gazów i spienianiem kiszonki. Następuje również usunięcie tlenu ze środowiska, w wyniku czego zahamowany zostaje rozwój niepożądanej mikroflory tlenowej oraz aktywność rodzimych enzymów kapusty. Kolejna faza będąca właściwą fermentacją mlekową trwa do ok. 10. - 16. dnia po zasoleniu. W tym czasie ma miejsce intensywny rozwój bakterii względnie i bezwzględnie heterofermentatywnych (Lactobacillus brevis, Lactobacillus plantarum i Pediococcus). Dojrzewanie kiszonki następuje po ok. dwóch tygodniach fermentacji i jest ostatnią fazą procesu. Kształtują się wtedy ostateczne cechy sensoryczne produktu, na które składają się produkty metabolizmu bakterii oraz związki powstające w procesie przemian chemicznych [12].

W początkowej fazie fermentacji kiszonek warzywnych drożdże bywają bardzo liczną oraz różnorodną grupą mikroorganizmów. Czasami zdarza się nawet, że zaczynają dominować i kontrolować proces fermentacji. W procesie fermentacji kiszonek warzywnych negatywna działalność drożdży prowadzi do wzrostu pH, który może 
zostać spowodowany przez jeden z dwóch procesów. Pierwszy wiąże się z tym, że obecne w kiszonce drożdże przeprowadzają fermentację, wykorzystując do tego cukry, które powinny zostać przefermentowane przez bakterie na kwas mlekowy. Drugi z procesów jest związany z rozwojem drożdży Geotrichum candidum oraz Candida mycoderma na powierzchni kiszonki przy zachowanym dostępie tlenu. Powyższe mikroorganizmy jako źródło węgla wykorzystują kwasy organiczne stabilizujące produkt. Powoduje to zmniejszenie kwasowości oraz wzrost $\mathrm{pH}$ i stwarza warunki do rozwoju bakterii gnilnych, które powodują psucie [12]. Drożdże są również odpowiedzialne za produkcję dużej ilości gazów [10]. Tworzą także metabolity wpływające ujemnie na smak i aromat kiszonki. Zbyt miękka struktura kiszonki może być związana z niedostatecznym stężeniem soli. Powinna ona zostać dodana do świeżo poszatkowanej kapusty w takiej ilości, aby stymulować wzrost pożądanych bakterii mlekowych w odpowiedniej kolejności. Kwas mlekowy oraz sól decydują o prawidłowej twardości produktu poprzez hamowanie enzymów pektynolitycznych [6]. Bardzo duże straty ekonomiczne w przemysłowej produkcji kiszonej kapusty powoduje pojawienie się wadliwego różowego zabarwienia. Wada ta wiąże się przeważnie ze zbyt dużą ilością dodanej do kiszonki soli, której stężenie przekracza $3 \%$. Za nieswoistą barwę odpowiedzialne są zazwyczaj drożdże z rodzaju Rhodotorula. Wytwarzają one karotenoidy, które nadają kiszonce różowe zabarwienie [18]. Wady w postaci obcego posmaku oraz zapachu, które są niespecyficzne dla produktów kiszonych i kojarzą się bardziej z przemysłem drożdżowniczym powstają najczęściej na skutek zbyt szybkiego procesu fermentacyjnego prowadzonego w wysokiej temperaturze. Warunki te sprzyjają rozwojowi mikroorganizmów tlenowych, głównie drożdży i pleśni, które produkują metabolity odpowiedzialne za niepożądany smak i zapach. Kiszona kapusta, w której doszło do rozwoju drożdży i pleśni, charakteryzuje się dużą zawartością estrów odpowiadających za aromat surowej kapusty, natomiast ilość kwasu mlekowego jest w niej znacznie mniejsza w porównaniu z produktami, w których mikroflora zanieczyszczająca nie występowała [6].

Celem pracy było określenie mikroflory drożdżowej występującej w kapuście kiszonej produkowanej przemysłowo oraz otrzymywanej w wyniku spontanicznej fermentacji w gospodarstwach rolnych w okolicach Muszyny.

\section{Materiał i metody badań}

Materiał do badań stanowiły trzy próbki produktów komercyjnych dostępnych w handlu: sok z kwaszonej kapusty (W), kapusta kwaszona z marchewką (D), kapusta kwaszona (K) oraz 3 próbki kapusty kiszonej uzyskane w wyniku spontanicznej fermentacji u lokalnych producentów w okolicach Muszyny: Muszyna (M), Powroźnik (P), Szczawnik (S). 
Identyfikacja wyizolowanych mikroorganizmów następowała przy wykorzystaniu metod polegających na łańcuchowej reakcji polimerazy oraz sekwencjonowania regionu ITS.

Pobierano po $1 \mathrm{~g}$ kiszonej kapusty wraz z solanką (w trzech powtórzeniach), a po odpowiednim rozcieńczeniu wykonywano posiewy na szalki Petriego z agarem WL (Biocorp Polska Sp. z o. o.) z dodatkiem 0,1 g/l chloramfenikolu. Posiewy inkubowano w cieplarce w temp. $28{ }^{\circ} \mathrm{C}$ przez $72 \mathrm{~h}$. Po zakończonej inkubacji dokonywano oceny makroskopowej oraz analizy ilościowej.

Pojedyncze kolonie drożdży przeszczepiano na podłoże Sabouraud Dextrose LAB-Agar (BioMaxima S.A., Polska). Skosy inkubowano w temp. $28{ }^{\circ} \mathrm{C}$. W celu namnożenia hodowle drożdży ze skosów przeszczepiano na podłoże płynne Sabouraud Dextrose Broth (BioMaxima S.A., Polska).

Do izolacji genomowego DNA stosowano zestaw do izolacji Genomic Mini AX YEAST SPIN (A\&A Biotechnology, Polska). Wyizolowane DNA amplifikowano z użyciem zestawu ONETaq DNA Polymerase (New England Biolabs) oraz startera M13 (5'GAGGGTGGCGGTTCT3'). Program amplifikacji obejmował: wstępną denaturację $\left(1 \mathrm{cykl}, 5 \mathrm{~min}, 95^{\circ} \mathrm{C}\right)$, po 35 cykli denaturacji $\left(1 \mathrm{~min}, 95^{\circ} \mathrm{C}\right)$, wiązania starterów $\left(1 \mathrm{~min}, 36^{\circ} \mathrm{C}\right) \mathrm{i}$ elongację $\left(2 \mathrm{~min}, 68^{\circ} \mathrm{C}\right)$ oraz końcową elongację $\left(7 \mathrm{~min}, 68^{\circ} \mathrm{C}\right)$. Wyniki amplifikacji analizowano na żelu agarozowym z dodatkiem bromku etydyny. Po zakończeniu rozdziału dokonywano wizualizacji elektroforegramu w transluminatorze UV. Wyniki archiwizowano w postaci zdjęć.

Izolaty różniące się profilem RAPD-PCR identyfikowano poprzez sekwencjonowanie regionu ITS (ITS1 - 5' TCCGTAGGTGAACCTGCGG-3' oraz ITS4 - 5'TCCTCCGCTTATTGATATGC-3'). Zamplifikowany materiał oczyszczano z użyciem zestawu Clean up AX zgodnie z instrukcją producenta i przekazywano do sekwencjonowania, które było prowadzone przez firmę Macrogen (Holandia). Uzyskane wyniki przetwarzano $\mathrm{z}$ użyciem programu MEGA 7.0.26 build 7170509 (http://www.megasoftware.net). Gatunki identyfikowano z użyciem bazy Genbank i narzędzi BLAST (http://www.ncbi.nlm.nih.gov/BLAST/).

\section{Wyniki i dyskusja}

Na podstawie wyników oznaczenia ilościowego drożdży w badanych próbkach kapusty kiszonej uzyskane metodą płytkową wykazano, że więcej komórek drożdżowych było obecnych w produktach otrzymanych metodami tradycyjnymi w gospodarstwach rolnych niż w produktach handlowych (rys. 1). Brak mikroflory drożdżowej w dwóch z trzech analizowanych produktów komercyjnych mógł być spowodowany procesami utrwalania, jakim zostały poddane. Według informacji od producenta, sok z kwaszonej kapusty (W) konserwowany był przez pasteryzację. Często do kiszonej kapusty stosowany jest również dodatek kwasu sorbowego, który skutecznie hamuje 
wzrost mikroflory drożdżowej i innych grzybów [13]. Kolejną przyczyną braku drożdży może być sposób produkcji. Zdarza się, że sprzedawana w opakowaniach kapusta kiszona jest uzyskiwana nie w procesie fermentacji mlekowej, ale poprzez zalanie poszatkowanego surowca octem lub kwasem mlekowym. Ilość drożdży obecnych w kiszonej kapuście zależy od naturalnej mikroflory występującej na świeżym warzywie oraz od warunków fermentacji, głównie temperatury i dodatku soli.

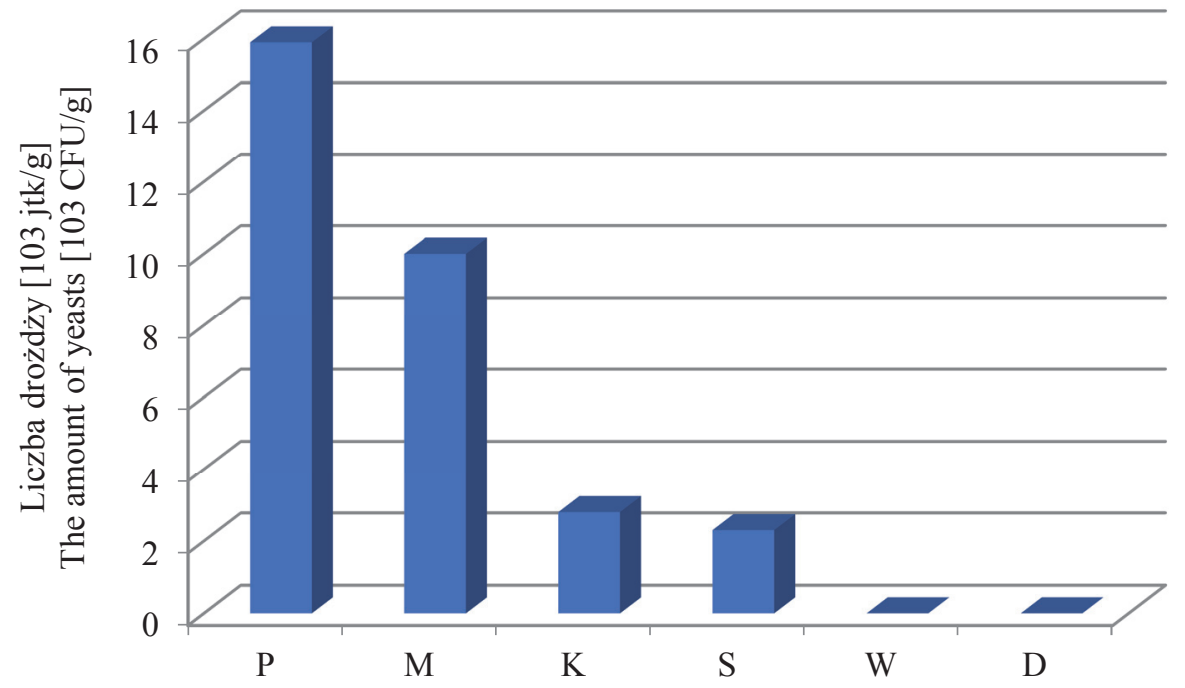

Objaśnienia / Explanatory notes:

P - kapusta kiszona z Powroźnika / farm-made sauerkraut from Powroźnik; M - kapusta kiszona z Muszyny / farm-made sauerkraut from Muszyna; S - kapusta kiszona ze Szczawnika / farm-made sauerkraut from Szczawnik; K - kapusta kwaszona komercyjna / commercially produced sauerkraut; W - sok z kwaszonej kapusty / commercially made sauerkraurt juice, D - kapusta komercyjna kwaszona z marchewką / commercially made sauerkraut with carrot.

Rys. 1. Liczba drożdży w analizowanych próbkach kiszonej kapusty

Fig. 1. Amount of yeasts in analyzed samples of sauerkraut

Jak podają Viander i wsp. [20], w soku z kiszonej kapusty o zawartości 1,2 \% soli występuje ponad $9 \cdot 10^{3} \mathrm{jtk} / \mathrm{g}$ drożdży, a ich liczba maleje $\mathrm{w}$ miarę przechowywania gotowego produktu w warunkach chłodniczych. Podwyższenie stężenia $\mathrm{NaCl}$ w solance z 0,8 do $1,5 \%$ skutkuje kilkukrotnym obniżeniem liczby drożdży w produkcie finalnym [21]. Należy więc przypuszczać, że wysoki poziom drożdży w kapuście kiszonej z Powroźnika i Muszyny może świadczyć o krótkim czasie przechowywania produktu, ewentualnie o niższym stężeniu $\mathrm{NaCl}$ w solance. Wyższe stężenie soli 
w kiszonce lub przechowywanie produktów w niskiej temperaturze może być przyczyną mniejszej liczby drożdży w kapustach S i K. W przypadku kapusty K, która jest produktem przemysłowym, na ograniczenie liczby mikroorganizmów mógł mieć wpływ sposób utrwalania.

A)

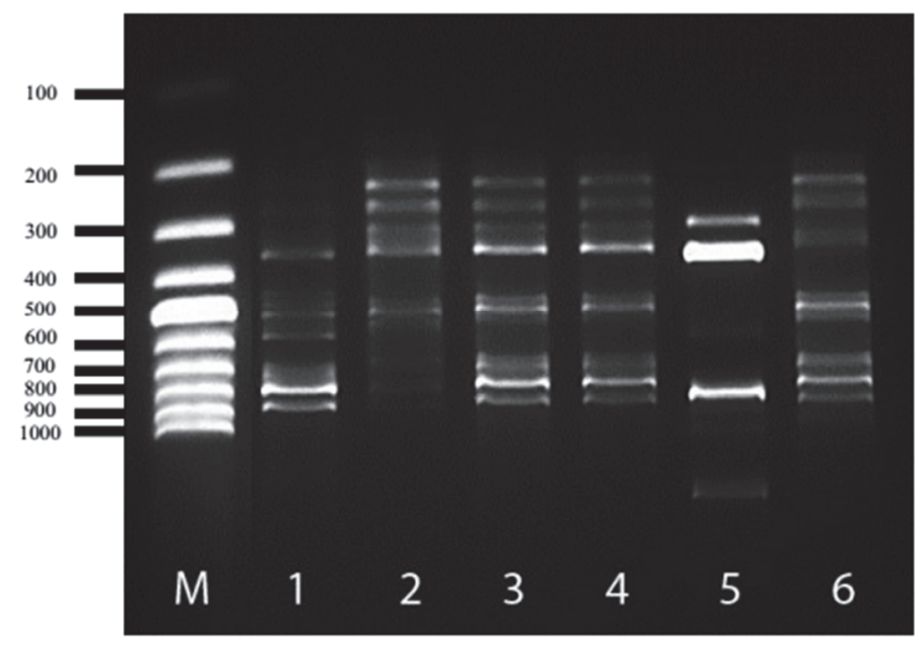

B)

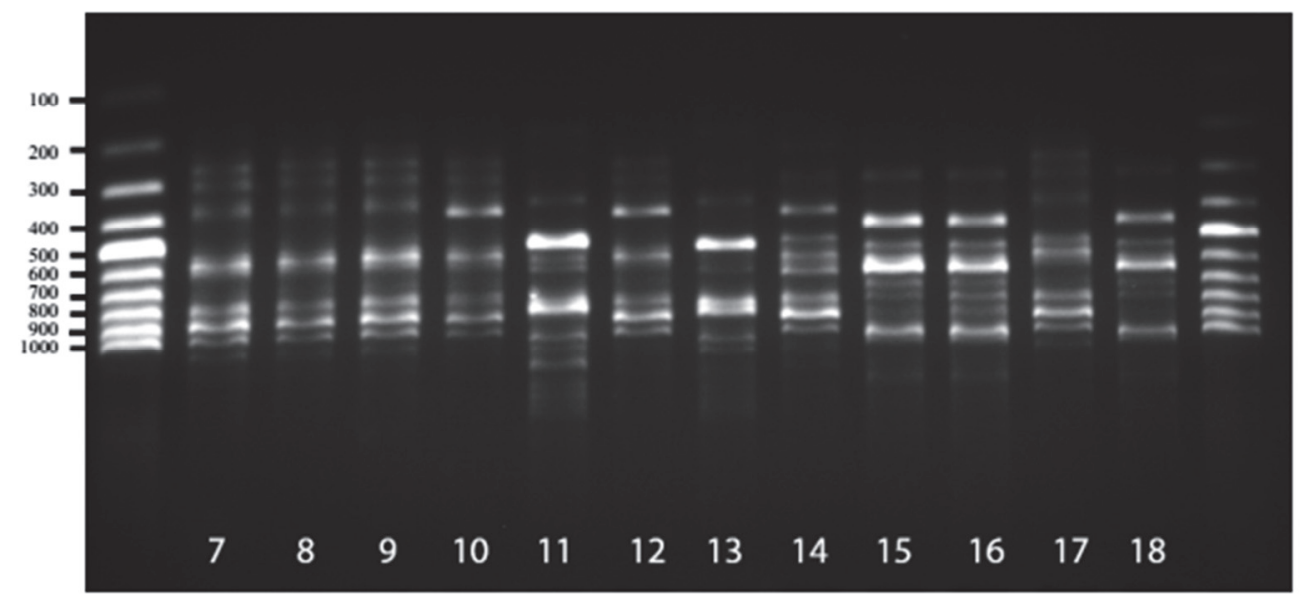

Rys. 2. Wyniki rozdziału elektroforetycznego produktów reakcji RAPD-PCR przy udziale startera M13. A) izolatów drożdżowych 1 - 6, B) izolatów drożdżowych 7 - 18

Fig. 2. Results of electrophoresis of RAPD-PCR products with M13 starter. A) for yeast isolates $1-6$, B) for yeast isolates $7-18$ 
Na rys. 2. (A i B) przedstawiono wyniki rozdziału produktów reakcji RAPD-PCR analizowanych szczepów drożdży. W wyniku badania 18 szczepów wyizolowanych z próbek kapusty kiszonej otrzymano 4 różne profile elektroforetyczne. Podobny układ prążków otrzymano w przypadku izolatów:

- $1,2,3,4,6,7,8,9,10,12,14,17$ - intensywne prążki przy długości 550 i $900 \mathrm{pz}$ (profil 1),

- $15,16,18$ - intensywne prążki przy długości 400 i 600 pz (profil 2),

- 11,13 - intensywne prążki przy długości 500 i 800 pz (profil 3),

- 5 - intensywne prążki przy długości 400 i 800 pz (profil 4).

Świadczy to o obecności w badanych próbkach 4 różnych szczepów drożdży. Sekwencjonowanie regionu ITS umożliwiło zaklasyfikowanie izolatów do dwóch gatunków - Debaryomyces hansenii (profil 2, 3 i 4) oraz Cryptococcus macerans (profil 1). Zidentyfikowane mikroorganizmy były już stwierdzane we wcześniejszych badaniach jako mikroflora obecna podczas procesu kiszenia kapusty [2]. Nie stwierdzono ich natomiast podczas analiz polskiej kiszonej kapusty [9], co, jak należy przypuszczać, mogło być związane z metodami użytymi do identyfikacji szczepów przez autorów wspomnianej publikacji. Stosując metody API 32C oraz PCR-RFLP, łatwo można dokonać mylnej klasyfikacji szczepów. $Z$ tego względu w przypadku grzybów wymagane jest potwierdzenie wyników poprzez sekwencjonowanie najczęściej regionu ITS. Należy pamiętać również o tym, że skład mikroflory w trakcie fermentacji spontanicznej uzależniony jest w znacznym stopniu od miejsca pochodzenia surowca, warunków klimatycznych panujących podczas jego wzrostu, technologii produkcji itd.

Na podstawie wyników RAPD-PCR oraz sekwencjonowania w populacji wyizolowanych kultur Debaryomyces hansenii wyróżniono 3 różne profile tych drożdży. Profil 1 zaobserwowano w kiszonej kapuście pochodzącej z gospodarstwa w Szczawniku (100\% izolatów) oraz w produkcie komercyjnym - kapuście kwaszonej (50 \%), profil 2 był charakterystyczny dla kiszonki z gospodarstwa w Muszynie (22 \%), natomiast 3 - jedynie dla próbek komercyjnych (25\%). Można przypuszczać, że obecność danego profilu drożdży Debaryomyces hansenii, uzależniona była od stosowanej technologii produkcji kiszonej kapusty oraz użytej odmiany surowca.

Gatunek Debaryomyces hansenii, teleomorf drożdży Candida famata, jest szeroko rozpowszechniony w naturze oraz w licznych produktach zawierających dużą ilość soli [19]. Jego zdolność do tolerancji wysokich stężeń $\mathrm{NaCl}$ (nawet do $24 \%$ ) powoduje, że jest często spotykany w solankach stosowanych do produkcji oliwek, serów, fermentowanych napojów mlecznych oraz sosu sojowego koji. $D$. hansenii był również często izolowany $\mathrm{z}$ fermentowanych wędlin, w których powodował pojawianie się ciemnych plamek na dojrzewającym salami [15]. Drobnoustroje te zaliczane są do grupy drożdży o metabolizmie tlenowym i często wiązane $\mathrm{z}$ tworzeniem kożucha na powierzchni solanki, np. podczas produkcji kiszonych ogórków [3]. Ze względu na 
produkcję enzymów z grupy proteinaz, ksylanaz i pektynaz mogą przyczyniać się do mięknięcia owoców i warzyw [7]. Deak i Beuchat [2] podają, że drożdże Debaryomyces hansenii rozwijają się wyłącznie na początku procesu fermentacji kapusty i ich populacja stopniowo zamiera. Warunki semi-anaerobowe lub tlenowe mogą znacząco zwiększyć żywotność tych mikroorganizmów i spowodować, że pojawią się one również w produkcie finalnym.

Drożdże Cryptococcus macerans stwierdzono w kapuście kiszonej pochodzącej z gospodarstw w Muszynie (78 \% izolatów) i Powroźniku (100\% izolatów), a także w jednym z produktów komercyjnych - kapuście kwaszonej (25\% izolatów). Cryptococcus macerans wraz ze swoim teleomorfem Cystofilobasidium sklasyfikowane zostały w rzędzie Cystofilobasidiales na podstawie analizy sekwencji 26S rDNA [11]. Cechą charakterystyczną przedstawicieli tego rodzaju jest wytwarzanie pigmentów karotenoidowych, substancji skrobiopodobnych, zdolność do wykorzystywania D-glukuronianu oraz inozytolu jako jedynego źródła węgla oraz asymilacja azotanów jako jedynego źródła azotu. Kultury Cryptococcus macerans izolowane były z różnych środowisk - ze słomy lnu, powierzchni zbóż i kwiatów, gleby, wody oraz ze słodu jęczmiennego. Rodzaj Cryptococcus w dużej ilości $\left(10^{8} \mathrm{jtk} / \mathrm{g}\right)$ stwierdzano na powierzchni przechowywanej kapusty [5]. Cryptococcus macerans był również stwierdzany w początkowej fazie fermentacji Sayur asin - warzywnej kiszonki produkowanej w Indonezji [17]. Niewielkie jego ilości $10^{1} \div 10^{2} \mathrm{jtk} / \mathrm{ml}$ wykrywane były w pierwszym dniu fermentacji, natomiast jego wzrost hamowany był w wyniku powstawania warunków beztlenowych. Wiąże się to z typowym metabolizmem tlenowym wykazywanym przez większość przedstawicieli rodzaju Cryptococcus. Obecność tego mikroorganizmu w produkcie gotowym może świadczyć o tym, że zastosowano tradycyjną metodę kiszenia w naczyniach, do których dostęp ma tlen. Może to znacząco skracać okres przechowywania tego rodzaju kiszonek i z czasem powodować objawy zepsucia charakterystyczne dla tych powodowanych przez drożdże z rodzaju Rhodotorula [18].

\section{Wnioski}

1. Kiszona kapusta wytwarzana w gospodarstwach rolnych w gminie Muszyna charakteryzowała się wyższym poziomem drożdży niż produkty komercyjne.

2. W badanych produktach stwierdzono obecność dwóch gatunków drożdży: Debaryomyces hansenii (3 szczepy) oraz Cryptococcus macerans (1 szczep), których obecność była ściśle uzależniona od badanej próbki.

3. Występowanie oznaczonych gatunków drożdży w gotowym produkcie może przyczyniać się do skracania czasu jego przydatności do spożycia i pojawiania się objawów zepsucia. 


\section{Badania finansowane ze środków Narodowego Centrum Nauki przyznanych na podstawie decyzji numer DEC-2014/15/B/NZ9/04527}

\section{Literatura}

[1] Beganović J., Kos B., Pavunc A.L., Uroić K., Jokić M., Šušković J.: Traditionally produced sauerkraut as source of autochthonous functional starter cultures. Microbiol. Res., 2014, 169, 7-8, 623632.

[2] Deak T., Beuchat L.R.: Handbook of Food Spoilage Yeasts. CRC Press, New York 1996.

[3] Etchells J.L., Bell T.A.: Classification of yeasts from the fermentation of commercially brined cucumbers. Farlowia, 1950, 4, 87-112.

[4] Filipiak T., Maciejczak M.: Vegetable production in Poland and selected countries of the European Union. Econ. Sci. Rural Dev., 2011, 24, 30-39.

[5] Fleet G.: Spoilage yeasts. Crit. Rev. Biotechnol., 1992, 12 (1-2), 1-44.

[6] Hang Y.D.: Sauerkraut. In: Handbook of Food and Beverage Fermentation Technology. Eds. Y.H. Hui, L. Meunier-Goddik, Å.S. Hansen, J. Josephsen, W.-K. Nip, P.S. Stanfield, F. Toldrá. Marcel Dekker Inc., New York 2004, pp. 669-676.

[7] Hernández A., Martín A., Córdoba M.G., Benito M.J., Aranda E., Pérez-Nevado F.: Determination of killer activity in yeasts isolated from the elaboration of seasoned green table olives. Int. J. Food Microbiol., 2008, 121 (2), 178-188.

[8] Kusznierewicz B., Śmiechowska A., Bartoszek A., Namieśnik J.: The effect of heating and fermenting on antioxidant properties of white cabbage. Food Chem., 2008, 108, 853-861.

[9] Lazar Z., Piegza1 M., Walczak E., Barszczewski W., Robak M.: Mikroflora drożdżowa naturalnie fermentowanych warzyw. Acta Sci. Pol., Biotechnol., 2013, 12 (1), 19-36.

[10] Li K-Y.: Fermentation. In: Handbook of Food and Beverage Fermentation Technology. Eds. Y.H. Hui, L. Meunier-Goddik, Å.S. Hansen, J. Josephsen, W.-K. Nip, P.S. Stanfield, F. Toldrá. Marcel Dekker Inc., New York 2004, pp. 595-610.

[11] Libkind D., Gadanho M., van Broock M., Sampaio J.P.: Cystofilobasidium lacus-mascardii sp. nov., a basidiomycetous yeast species isolated from aquatic environments of the Patagonian Andes, and Cystofilobasidium macerans sp. nov., the sexual stage of Cryptococcus macerans. Int. J. Syst. Evol. Microbiol., 2009, 59, 622-630.

[12] Libudzisz L., Kowal K., Żakowska Z.: Mikrobiologia techniczna. T. 2. Wyd. Nauk. PWN, Warszawa 2008 , ss. 43-45.

[13] Lück E.: Food applications of sorbic acid and its salts. Food Addit. Contam., 1990, 7 (5), 711-715.

[14] Peñas E., Frias J., Gomez R., Vidal-Valverde C.: High hydrostatic pressure can improve the microbial quality of sauerkraut during storage. Food Control, 2010, 21 (4), 524-528.

[15] Pitt I.J., Hocking A.D.: Yeasts. In: Fungi and Food Spoilage. Springer, Boston, MA, USA, 2009, pp. 357-382.

[16] Plengvidhya V., Breidt F., Fleming H.P.: Use of RAPD-PCR as a method to follow the progress of starter cultures in sauerkraut fermentation. Int. J. Food Microbiol., 2004, 93 (3), 287-296.

[17] Puspito H., Fleet G.H.: Microbiology of sayur asin fermentation. Appl. Microbiol. Biotechnol., 1985, 22, 442-445.

[18] Shih C.T., Hang Y.D.: Production of carotenoids by Rhodotorula rubra from sauerkraut brine. LTW-Food Sci. Technol., 1996, 29, 570-572.

[19] Vasdinyei R., Deák, T.: Characterization of yeast isolates originating from hungarian dairy products using traditional and molecular identification techniques. Int. J. Food Microbiol., 2003, 86 (1-2), 123-130.

[20] Viander B., Mäki M., Palva A.: Impact of low salt concentration, salt quality on natural large-scale sauerkraut fermentation. Food Microbiol., 2003, 20 (4), 391-395.

[21] Wiander B., Palva A.: Sauerkraut and sauerkraut juice fermented spontaneously using mineral salt, garlic and algae. Agric. Food Sci., 2011, 20, 169-175. 


\title{
IDENTIFYING YEAST OCCURRING IN COMMERCIAL AND FARM-MADE SAUERKRAUT
}

\author{
S u m m a r y
}

Sauerkraut is a commonly consumed product in Poland. It is still traditionally produced using spontaneous fermentation by indigenous microorganisms colonizing cabbage leaves, mainly lactic acid bacteria. During fermentation, yeasts may also become active and their negative activity can cause $\mathrm{pH}$ to increase and spoilage bacteria to develop.

The objective of the research study was to identify the yeast microbiota in sauerkraut produced industrially and by spontaneous fermentation in the farms in the region of Muszyna. The microorganisms were isolated using WL agar with $0.1 \mathrm{~g} / 1$ of chloramphenicol added, and the isolates were differentiated by RAPD-PCR fingerprinting with an M13 starter and identified by sequencing the ITS region. The largest amount of yeasts was found in the sauerkraut samples produced using traditional methods in the farms located in the Muszyna commune $\left(2.3 \div 15.9 \cdot 10^{3} \mathrm{CFU} / \mathrm{g}\right)$ and in one commercial product $\left(2.8 \cdot 10^{3} \mathrm{CFU} / \mathrm{g}\right)$. In other commercial sauerkraut products analyzed, no yeast was found. Among the isolates, the representatives of two species: Cryptococcus macerans and Debaryomyces hansenii were identified; the second one was differentiated by RAPD-PCR into 3 different profiles. The identified microorganisms present were highly dependent on the sample under analysis; this could be linked with the production technology of sauerkraut and, also, with the variety of raw material used. The occurrence of the identified yeast species in the final product can cause the shelf-life of sauerkraut to diminish and the signs of its spoilage to appear.

Key words: sauerkraut, yeasts, PCR-RAPD, sequencing, Debaryomyces hansenii 